Breaking Bread 
CALIFORNIA STUDIES IN FOOD AND CULTURE

Darra Goldstein, Editor 


\section{Breaking Bread}

RECIPES AND STORIES FROM

IMMIGRANT KITCHENS

Lynne Christy Anderson

Foreword by Corby Kummer

Photographs by Robin Radin

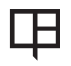

UNIVERSITY OF CALIFORNIA PRESS

BERKELEY LOS ANGELES LONDON 
University of California Press, one of the most distinguished university presses in the United States, enriches lives around the world by advancing scholarship in the humanities, social sciences, and natural sciences. Its activities are supported by the UC Press Foundation and by philanthropic contributions from individuals and institutions. For more information, visit www.ucpress.edu.

University of California Press

Berkeley and Los Angeles, California

University of California Press, Ltd.

London, England

(C) 2010 by Lynne Christy Anderson

Photographs (C) 2010 by Robin Radin

Library of Congress Cataloging-in-Publication Data Anderson, Lynne Christy.

Breaking bread : recipes and stories from immigrant kitchens / Lynne Christy Anderson ; foreword by Corby Kummer ; photographs by Robin Radin.

p. $\quad \mathrm{cm}$ - (California studies in food and culture ; 29) ISBN-I3: 978-0-520-26257-7 (cloth : alk. paper)

I. Cookery, International. 2. Food habits-United States. 3. Immigrants—United States—Anecdotes.

I. Title.

$\mathrm{TX}_{725}$.AIA564 2010 394.' '20973-dc22 20090439II

Manufactured in the United States of America

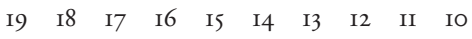

IO $\quad 9 \begin{array}{lllllllll} & 8 & 7 & 6 & 5 & 4 & 3 & 2 & \text { I }\end{array}$

The paper used in this publication meets the minimum requirements of ANSI/NISO Z39.48-1992 (R 1997)

(Permanence of Paper). 
For my mother, who instilled in me the pleasures of cooking and eating, and for my father, who taught me to listen to my students 
This page intentionally left blank 
There is a communion of more than our bodies when bread is broken and wine drunk.

M. F. K. FISHER, The Gastronomical Me, 1943 
This page intentionally left blank 